\title{
Alternaria Fungus Induces the Production of GM-CSF, Interleukin-6 and Interleukin-8 and Calcium Signaling in Human Airway Epithelium through Protease-Activated Receptor 2
}

\author{
Yoshinori Matsuwaki ${ }^{a, b}$ Kota Wada ${ }^{a, b}$ Thomas White ${ }^{a}$ Hiroshi Moriyama $^{b}$ \\ Hirohito Kita ${ }^{a}$ \\ a Departments of Immunology and Medicine, Mayo Clinic, Rochester, Minn., USA; ${ }^{b}$ Department of \\ Otorhinolaryngology, The Jikei University School of Medicine, Tokyo, Japan
}

\section{Key Words}

Airway epithelium · Alternaria $\cdot$ Aspartate protease $\cdot$

Fungi $\cdot$ Protease-activated receptor 2

\begin{abstract}
Rationale: Recent studies suggest that host immune responses to environmental fungi may play an important role in the development of allergic diseases, such as human asthma. Epithelium is considered an active participant in allergic inflammation. We previously reported that aspartate protease from Alternaria induces the activation and degranulation of human eosinophils that are mediated through proteaseactivated receptor 2 (PAR-2). However, our current knowledge on the innate immune responses of epithelium to environmental fungi is very limited. We investigated the responses of epithelium to fungi and the mechanisms of these responses. Methods: Human airway epithelial cell line BEAS$2 \mathrm{~B}$ and Calu-3 (both from American Type Culture Collection) were incubated with PAR-2 peptides and extracts of various fungi. The cellular responses, including GM-CSF, interleukin (IL)-6, IL-8, eotaxin, eotaxin-2 and RANTES production as well as increases in intracellular calcium concentration $\left(\left[\mathrm{Ca}^{2+}\right]_{\mathrm{i}}\right)$,
\end{abstract}

were examined. To characterize the proteases involved in these responses, protease inhibitors such as pepstatin $A$ and alkalo-thermophilic Bacillus inhibitor (ATBI), HIV protease inhibitors and 4-amidinophenylmethanesulfonyl fluoride hydrochloride were used. To investigate the role of PAR-2, PAR2-agonistic and PAR-2-antagonistic peptides were used. $\boldsymbol{R e}$ sults: PAR-2-activating peptide, but not the control peptide, induced GM-CSF, IL- 6 and IL-8 production; these cellular responses were accompanied by a quick and marked increase in $\left[\mathrm{Ca}^{2+}\right]_{\mathrm{i}}$. Among 7 common environmental fungi, only Alternaria induced GM-CSF, IL- 6 and IL-8 production and increased $\left[\mathrm{Ca}^{2+}\right]_{i}$ response. Both cytokine production and increased $\left[\mathrm{Ca}^{2+}\right]_{i}$ were significantly inhibited by PAR-2 antagonist peptide and by aspartate protease inhibitors (pepstatin A, ritonavir, nelfinavir and ATBI), but not by the PAR-2 control peptide or by other protease inhibitors. Conclusions: Aspartate proteases from Alternaria induce cytokine production and calcium response in airway epithelium that is mediated through PAR-2. This protease-mediated activation of airway epithelium may be implicated in the development and exacerbation of airway allergic disease.

Copyright $\odot 2012$ S. Karger AG, Basel

Correspondence to: Dr. Yoshinori Matsuwak

Department of Otorhinolaryngology, The Jikei University School of Medicine 3-25-8 Nishi-shinbashi, Minato-ku

Tokyo 105-8461 (Japan)

Tel. +81 33433 1111, ext. 3601 2, E-Mail matuwaki@jikei.ac.jp 


\section{Introduction}

Fungi are environmentally ubiquitous and, except when invasive, generally not thought to be harmful or pathological. However, epidemiological and clinical reports recognize associations between asthma and allergic diseases and the presence of, or exposure to, airborne fungi such as Alternaria (in North America), Cladosporium and Aspergillus (in Europe) [1]. Allergic sensitivity to, and the airborne presence of Alternaria are associated with the development and persistence of asthma [2]. In a large multi-country, cross-sectional study, sensitization to Alternaria or Cladosporium, but not to pollens or cats, was found to be a significant risk factor for severe asthma (odds ratio: 2.34) [3], while exposure to Alternaria was a risk factor for respiratory arrest in patients with asthma [4]. Humans are constantly exposed to various fungal spores, perhaps up to 1,000 times more than to pollens [5], but only a few fungi have been implicated in allergy and asthma. Thus, a major question remains: how do humans develop immune and inflammatory responses to particular fungal genera?

The human respiratory epithelium is the first interface with airborne pathogens or allergens. Upon activation, they produce antimicrobial molecules, proinflammatory cytokines and chemokines for the recruitment of immune cells to the local airway via pattern recognition receptors. These pattern recognition receptors recognize conserved structural motifs expressed by microbial pathogens or pathogen-associated molecular patterns (PAMPs) [6-8]. Among the pattern recognition receptors, protease-activated receptors (PARs) are widely distributed on the cells of the airways, where they contribute to the inflammation characteristic of allergic diseases [9]. PAR stimulation of epithelial cells opens tight junctions, causes desquamation and produces cytokines, chemokines and growth factors $[9,10]$. PAR-2, apparently the most important of the 4 PARs that have been characterized, is increased on the epithelium of patients with asthma [10]. Cysteine protease activity from Alternaria induces epithelium thymic stromal lymphopoietin (TSLP) production through PAR-2 in vitro [11]. TSLP is thought to be necessary and sufficient cytokine for the development of Th2-type airway inflammation $[12,13]$. Furthermore, airway exposure of naive mice to Alternaria induces rapid secretion of interleukin (IL)-33 into the airways and subsequent Th2-type cytokine production. In response to Alternaria allergens, airway epithelial cells translocate nuclear IL-33 and actively release it into the extracellular milieu via ATP-mediated activation of P2 purinergic receptors [14]. In addition, human eosinophils show an innate immune response to aspartate proteases from Alternaria via PAR-2 [15]. However, little information is available to explain how environmental fungi induce proinflammatory cytokine, such as IL-6, IL-8 and GM-CSF, and eosinophil-recruiting chemokines, such as eotaxin, eotaxin-2 and RANTES, by airway epithelium. Here, we hypothesize that environmental fungi directly induce activation, i.e. an increased intracellular calcium concentration $\left[\mathrm{Ca}^{2+}\right]_{i}$ response, proinflammatory cytokine production and eosinophil-recruiting chemokine production by human airway epithelium, which are mediated through PAR-2. In this study, we investigated the responses of airway epithelium to 7 environmental common fungi and the mechanisms of these responses. Among them, only Alternaria induced GM-CSF, IL-6 and IL-8 production and increased $\left[\mathrm{Ca}^{2+}\right]_{\mathrm{i}}$ response. Both cytokine production and increased $\left[\mathrm{Ca}^{2+}\right]_{\mathrm{i}}$ were significantly inhibited by PAR- 2 antagonist peptide and by aspartate protease inhibitors [pepstatin A, ritonavir, nelfinavir and alkalothermophilic Bacillus inhibitor (ATBI)], but not by the PAR-2 control peptide and other protease inhibitors, suggesting an aspartate protease-mediated mechanism through PAR-2. This protease-mediated activation of airway epithelium may be implicated in the development and exacerbation of airway allergic disease.

\section{Materials and Methods}

\section{Materials}

Culture filtrate extracts from Alternaria alternata, Aspergillus versicolor, Aspergillus fumigatus, Candida albicans, Cladosporium herbarum, Penicillium and Curvularia were from Greer Laboratories (Lenoir, N.C., USA). The extracts were derived from the media in which the fungi were grown; as they grow, they excrete proteins into the media. After removing the media components, the culture filtrates were concentrated, dialyzed and lyophilized. 4-Amidinophenylmethanesulfonyl fluoride hydrochloride ( $\mathrm{p}$ APMSF) was from Sigma Aldrich Chemical Company (St. Louis, Mo., USA). Ionomycin and ATBI were from Calbiochem (San Diego, Calif., USA). Fura-2 acetoxymethyl (Fura-2/AM) solution was from Molecular Probes Inc. (Eugene, Oreg., USA). PAF was from BIOMOL International (Plymouth Meeting, Pa., USA). Pepstatin A agarose and control agarose were from PIERCE (Rockford, Ill., USA). HIV protease inhibitors, ritonavir and nelfinavir, were provided by Badley Andrew's laboratory (Mayo Clinic, Rochester, Minn., USA). 4-(2-Aminoethyl)benzenesulfonyl fluoride hydrochloride (AEBSF) was from Fluka. Tethered ligand peptides specific for human PAR-2 used in this study are as follows: PAR-2 agonistic peptides, Ser-Leu-Ile-Gly-Lys-Val-NH2 (SLIGKV), PAR-2 antagonistic peptide, Leu-Ser-Ile-Gly-Lys-ValNH2 (LSIGKV) and PAR-2 control peptide, Gly-Leu-Ile-Val-LysSer-NH2 (GLIVKS). These peptides were made in-house. ELISA kits of GM-CSF, IL-6, IL-8, eotaxin, eotaxin-2 and RANTES were from R\&D Systems.
Matsuwaki/Wada/White/Moriyama/ Kita 
Epithelial Cell Culture and Treatment

The human bronchial epithelial cell line, BEAS-2B (derived from human bronchial epithelium transformed by an adenovirus 12 -SV40 virus), and the human adenocarcinoma-derived cell line, Calu-3, were purchased from American Type Culture Collection. Cells from both were cultured in DMEM/F12 medium (Invitrogen) supplemented with $10 \%$ heat-inactivated $\left(30 \mathrm{~min}\right.$ at $\left.56^{\circ} \mathrm{C}\right)$ FBS (Life Technologies), $100 \mathrm{U} / \mathrm{ml}$ penicillin and $100 \mu \mathrm{g} / \mathrm{ml}$ streptomycin (Life Technologies) at $37^{\circ} \mathrm{C}$ and $5 \% \mathrm{CO}_{2}$. To prepare the cells for stimulation, they were seeded $\left(5 \times 10^{4}\right.$ cells/well) in a 24 well tissue culture plate (Corning Costar) and grown until $80 \%$ confluence (approx. 2 days). Cells were then incubated for up to $24 \mathrm{~h}$ with Alternaria extract $(25-75 \mu \mathrm{g} / \mathrm{ml})$ or TNF- $\alpha(1 \mathrm{ng} / \mathrm{ml})$. Cell culture supernatants and cell lysates were collected and used for some cytokine and chemokine protein ELISA (see below). Previous reports had noted that high concentrations of fungal extracts or proteases would produce morphologic changes and desquamate epithelial cells [16]. At the relatively low concentrations listed above, we did not observe changes in morphology in the cells for up to $24 \mathrm{~h}$.

\section{Eosinophil Isolation}

Human eosinophils were isolated from normal volunteers or patients with a history of asthma or allergic rhinitis or both by Percoll density-gradient centrifugation and magnetic cell-sorting using MACS anti-CD16 microbeads as described earlier [17]. The purity of eosinophils was regularly $>98 \%$. The Mayo Clinic Rochester Institutional Review Board approved the protocol to obtain blood from volunteers, all of whom provided informed consent.

\section{Measurement of Intracellular $\mathrm{Ca}^{2+}$}

Real-time changes in the $\left[\mathrm{Ca}^{2+}\right]_{\mathrm{i}}$ of epithelial cells and eosinophils were measured by microscope using the calcium indicator, Fura-2/AM. Briefly, BEAS-2B or Calu-3 cells were cultured on sterilized glass coverslips (\#0; Biophysica Technologies Inc.) for 1 day. Isolated eosinophils were placed on the same glass coverslips with HBSS with $10 \mathrm{mM}$ HEPES. On the day of experiment, the cells were loaded with Fura-2/AM (Molecular Probes Inc.) by incubating at room temperature for 25 min by HBSS with $1 \mu \mathrm{M}$ Fura-2/AM and 10 mM HEPES (pH 7.2). After the incubation, the coverslip was rinsed twice with HBSS with $10 \mathrm{mM}$ HEPES and mounted in an incubation chamber on the mechanical stage of a Nikon Diaphot microscope (Nikon, Garden City, N.Y., USA). The chamber was filled with $2 \mathrm{ml}$ of HBSS $10 \mathrm{mM}$ HEPES at room temperature during the experiment. At the times indicated, Alternaria (final concentration: $100-200 \mu \mathrm{g} / \mathrm{ml}$ ) and/or antagonists were added in volumes of $20 \mu \mathrm{l}$. Calcium ratio fluorometry was performed using a DeltaScan-4000 ratio fluorescence system (Photon Technology International, South Brunswick, N.J., USA) [18]. The fluorescent dye within the cells, Fura-2, was excited by alternating between 340 - and 380-nm excitation wavelengths, and the intensity of the intracellular emission fluorescence at $510 \mathrm{~nm}$ for each excitation wavelength was monitored in real time by an SIT microscope video camera (model C2400; Hamamatsu, Hamamatsu City, Japan). The $\left[\mathrm{Ca}^{2+}\right]_{\mathrm{i}}$ of each cell was calculated from the intensity ratio of fluorescence at the two excitation wavelengths according to the equation of Grynkiewicz et al. [19].

Innate Immune Response of Airway

Epithelium to Fungus
The Roles of PAR-2 in Eosinophil Response to Alternaria

To investigate the roles of PAR-2 in the epithelial activation and cytokine production to Alternaria extract, we preincubated the cells with $100 \mu \mathrm{M}$ LSIGKV, $100 \mu \mathrm{M}$ GLIVKS or medium alone for $15 \mathrm{~min}$ at room temperature before stimulation with $75 \mu \mathrm{g} / \mathrm{ml} \mathrm{Al}$ ternaria extract or $1 \mathrm{ng} / \mathrm{ml} \mathrm{TNF}-\alpha$ (final concentration). To investigate the roles of PAR-2 in the epithelial $\left[\mathrm{Ca}^{2+}\right]_{\mathrm{i}}$ response to Alternaria extract, the desensitization assay with PAR-2 agonists was performed. Epithelial cells, loaded with Fura-2 as described previously, were first incubated with $100 \mu \mathrm{M}$ PAR-2 peptide (SLIGKV, LSIGKV or GLIVKS) or medium alone for $20 \mathrm{~s}$, and then $75 \mathrm{mg} /$ $\mathrm{ml}$ Alternaria extract was added for an additional 5-10 min. Realtime changes in $\left[\mathrm{Ca}^{2+}\right]_{\mathrm{i}}$ were observed for up to $20 \mathrm{~min}$.

\section{The Effect of Protease Inhibitors in PAR-2 Activation}

To investigate the effects of heat treatment on the immunostimulatory activity of Alternaria extract, the extract or medium was exposed to 4 or $56^{\circ} \mathrm{C}$ for $30 \mathrm{~min}$ and restored to $37^{\circ} \mathrm{C}$ before use as stimulants for cytokine production. To investigate the effects of aspartate protease inhibitor, the stimulants (i.e. Alternaria extract and TNF- $\alpha$ ) were treated with half volume of Pepstatin-gel ${ }^{\circledR}$ (PIERCE, 0020215), Reacti-gel ${ }^{\circledR}$ (PIERCE, 0020260) as control agarose, or no agarose (medium alone) for $15 \mathrm{~min}$. Subsequently, these mixtures were centrifuged at $1,000 \mathrm{~g}$ for $5 \mathrm{~min}$. The supernatants were diluted and used for epithelial cytokine production assay and $\left[\mathrm{Ca}^{2+}\right]_{\mathrm{i}}$ response assay. The final concentrations of stimulants were as follows: Alternaria extract $100 \mu \mathrm{g} / \mathrm{ml}$ and TNF- $\alpha 10 \mathrm{ng} / \mathrm{ml}$. To investigate the effects of other protease inhibitors, the stimulants (Alternaria extract, TNF- $\alpha$ or medium alone) were treated with the same volume of 4.0-400 $\mu \mathrm{M}$ ATBI, $0.2-20 \mu \mathrm{M}$ ritonavir, 0.2-20 $\mu \mathrm{M}$ nelfinavir, 20-200 $\mu \mathrm{M}$ APMSF, 5-2 mM AEBSF or medium alone for $30 \mathrm{~min}$ at room temperature. These mixtures were then used for cytokine production assay and $\left[\mathrm{Ca}^{2+}\right]_{\mathrm{i}}$ assay. The final concentrations of the stimulants were as follows: Alternaria extract $100 \mu \mathrm{g} / \mathrm{ml}$ and TNF- $\alpha 10 \mathrm{ng} / \mathrm{ml}$.

\section{ELISA for GM-CSF, IL-6, IL-8, Eotaxin, Eotaxin-2 and}

\section{RANTES Protein}

Immunoreactive GM-CSF, IL-6, IL-8, eotaxin, eotaxin-2 and RANTES in the supernatants from BEAS-2B cells or Calu-3 cells were quantitated using a specific ELISA with matched antibodies according to the manufacturer's instructions (R\&D Systems).

\section{Statistics}

Data from at least 3 experiments derived from different donors were summarized and presented as mean \pm SEM. A 1-way ANOVA with a Tukey test, a Student $t$ test or a Mann-Whitney U test were used for the comparison of more than 2 variables. Significance was established at the level $\mathrm{p}<0.05$.

\section{Results}

\section{Effects of Various Fungal Extracts on Human Airway Epithelium}

The human airway epithelial cell lines, BEAS-2B and Calu-3, were incubated with extracts of various fungi. Among the extracts of 7 common environmental fungi, 


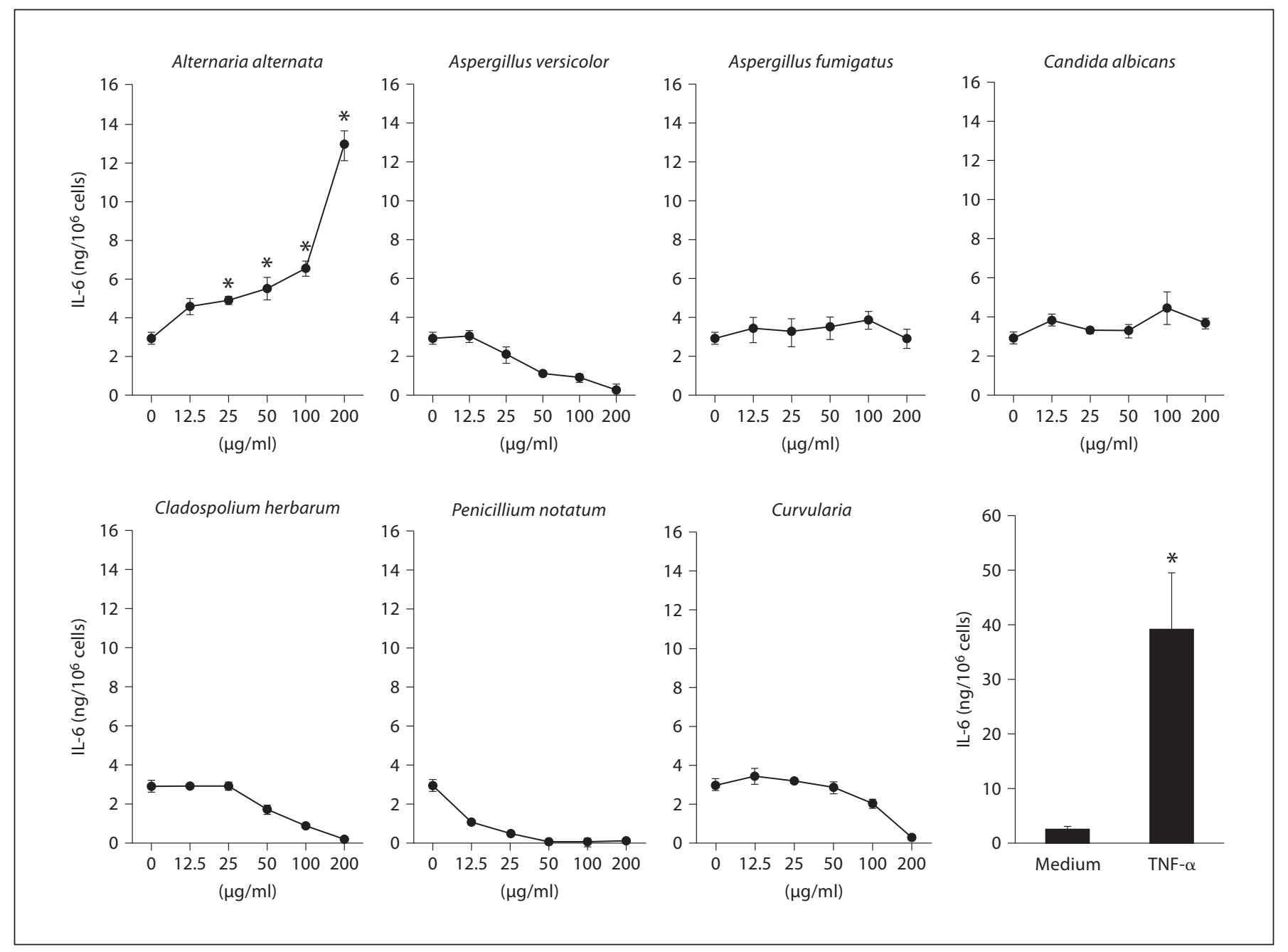

Fig. 1. Effects of extracts from various fungi on IL- 6 production by BEAS-2B cells. BEAS-2B monolayer was incubated with extracts of various fungi for $8 \mathrm{~h}$, and IL- 6 released into supernatants was measured by ELISA. Among extracts of 7 common environmental fungi, only $A$. alternata significantly induced IL- 6 production by BEAS- $2 B$ cells. $M \pm S E, n=5$. One-way ANOVA with Tukey's test was used. ${ }^{*} \mathrm{p}<0.05$, compared to medium alone. it was only A. alternata that significantly induced IL-6 production by BEAS-2B cells (fig. 1). Alternaria extract also significantly induced IL-8 and GM-CSF production by BEAS-2B cells (fig. 2). Furthermore, the responses of BEAS-2B cells to Alternaria extract were time- and dose-dependent (fig. 2). This extract also induced significant IL-8 production by Calu-3 cells (data not shown). It did not induce production of eotaxin, eotaxin- 2 or RANTES by BEAS-2B or Calu-3 cells (data not shown).

\section{Effects of PAR-2 Peptide on Human Airway Epithelial Cells}

To investigate the mechanisms involved in Alternariainduced cytokine production by epithelial cells, we first examined whether authentic agonists for PAR-2 can replicate what we observed with Alternaria extract. SLIGKV, a PAR-2 agonistic peptide, induced GM-CSF, IL- 6 and IL- 8 production in BEAS-2B cells in a dose-dependent manner (fig. 2). In contrast, a PAR-2 antagonist peptide, LSIGKV and a control peptide, GLIVKS, did not show any effects. The SLIGKV peptide did not induce eotaxin, eotaxin-2 or RANTES production. SLIGKV, but not LSIGKV and GLIVKS, also significantly induced IL-8 


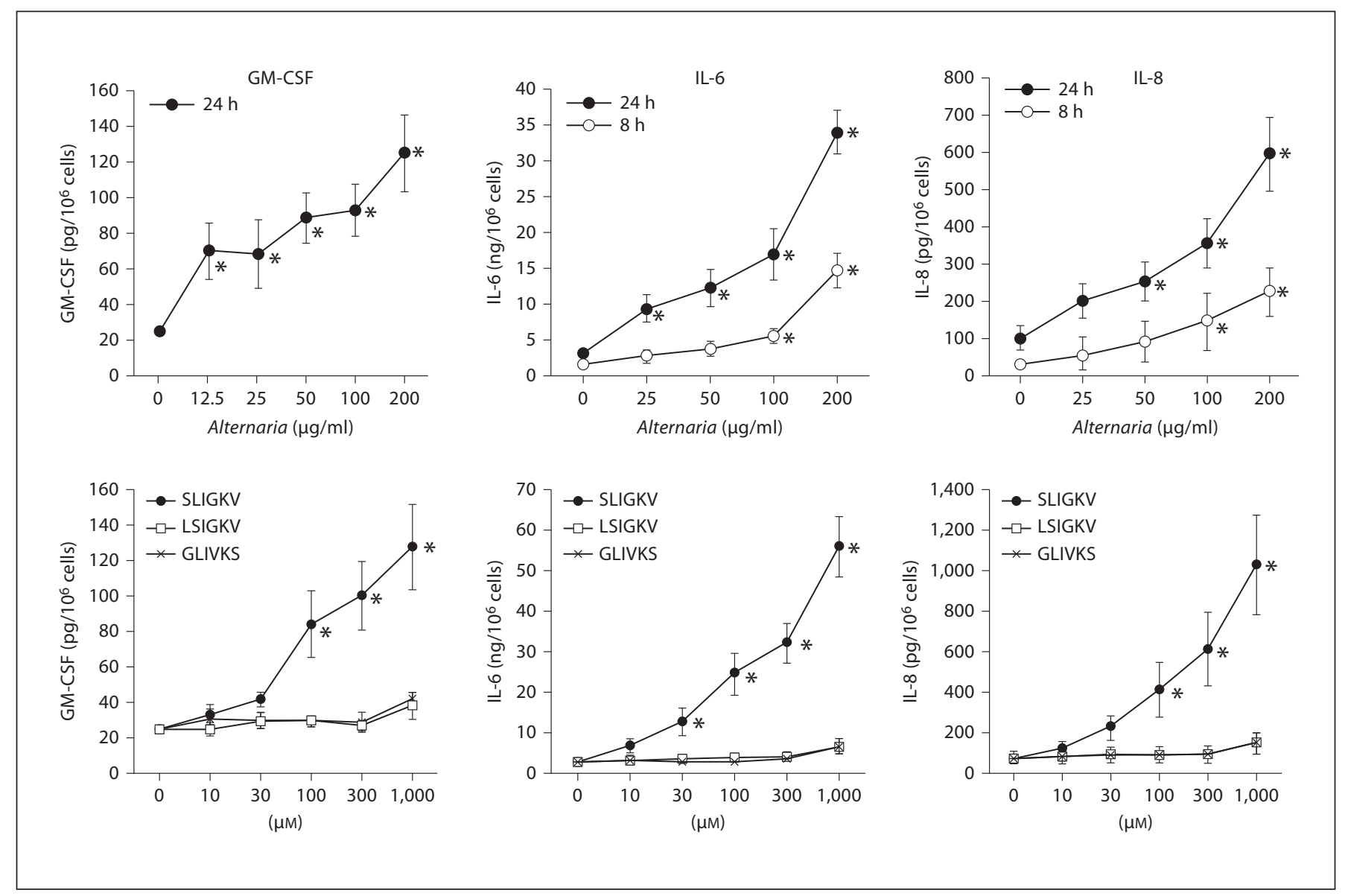

Fig. 2. Effects of Alternaria extracts and PAR-2 peptides on cytokine production by BEAS-2B cells. BEAS-2B cells were incubated with extracts of Alternaria or PAR-2 peptides for $8 \mathrm{~h}$, and GMCSF, IL- 6 and IL- 8 released into supernatants were measured by ELISA. Alternaria significantly induced GM-CSF, IL-6 and
IL-8 production in BEAS-2B cells in a dose-dependent manner. SLIGKV (PAR-2 agonistic peptide), but not LSIGKV (PAR-2 antagonistic peptide) or GLIVKS (control peptide), induced GMCSF, IL- 6 and IL- 8 production. $M \pm S E, ~ n=5$. One-way ANOVA with Tukey's test was used. ${ }^{*} \mathrm{p}<0.05$, compared to medium alone. production by Calu-3 cells (data not shown). Thus, both Alternaria extract and PAR-2 agonistic peptide potently induced the production of certain cytokines by airway epithelial cells.

\section{Alternaria-Induced $\left[\mathrm{Ca}^{2+}\right]_{i}$ in Human Airway Epithelial Cells and Eosinophils}

Human eosinophils stimulated with A. alternata extract showed rapid increases in cytosolic free $\mathrm{Ca}^{2+}$, i.e. $\left[\mathrm{Ca}^{2+}\right]_{\mathrm{i}}[15,20]$. Although the molecular mechanisms for eosinophil exocytosis are incompletely understood, increased $\left[\mathrm{Ca}^{2+}\right]_{i}$ is a key triggering step in the coupling of stimulus to secretion [21]. This $\left[\mathrm{Ca}^{2+}\right]_{\mathrm{i}}$ response was rapidly observed $200 \mathrm{~s}$ after stimulation and reached a peak between 400 to $600 \mathrm{~s}[15,20]$. In this study, to examine whether a similar $\left[\mathrm{Ca}^{2+}\right]_{i}$ response operates in epithelial cells, real-time changes in $\left[\mathrm{Ca}^{2+}\right]_{i}$ were measured in BEAS-2B cells as well as in human eosinophils (as a positive control) by using the fluorescent calcium indicator Fura-2 and fluorescent microscopy. Alternaria extract increased $\left[\mathrm{Ca}^{2+}\right]_{i}$ in purified human eosinophils in a way similar to previous studies (fig. 3b). BEAS-2B cells also showed similar increases in $\left[\mathrm{Ca}^{2+}\right]_{\mathrm{i}}$ when stimulated with Alternaria extract. Furthermore, a higher concentration $(200 \mu \mathrm{g} / \mathrm{ml})$ of Alternaria extract showed a quicker and stronger response than a lower concentration $(100 \mu \mathrm{g} /$ $\mathrm{ml}$ ) (fig. 3a). Indeed at $200 \mu \mathrm{g} / \mathrm{ml}$, the kinetics of the $\mathrm{Al}$ ternaria extract-induced $\left[\mathrm{Ca}^{2+}\right]_{\mathrm{i}}$ response were similar in eosinophils and epithelial cells. 
Fig. 3. The $\left[\mathrm{Ca}^{2+}\right]_{\mathrm{i}}$ responses in human epithelial cells (a) and eosinophils (b) when they are stimulated with Alternaria extract and PAR-2 agonistic peptide, SLIGKV. Real-time changes in $\left[\mathrm{Ca}^{2+}\right]_{i}$ were measured using microscopy and fluorescent calcium indicator Fula-2 as described in Materials and Methods. Alternaria extract increased $\left[\mathrm{Ca}^{2+}\right]_{\mathrm{i}}$ response in both epithelial cells and eosinophils. Ionomycine (Iono) and PAF were used as positive controls.

Fig. 4. Effects of heat treament and polymyxin B (PmB) on Alternaria extract. Aliquots of $100 \mu \mathrm{g} / \mathrm{ml}$ Alternaria extract were heated at $56^{\circ} \mathrm{C}$ for $30 \mathrm{~min}$, or were treated at $4^{\circ} \mathrm{C}$ for $30 \mathrm{~min}$. Alternatively, Alternaria extract was treated with an LPS inhibitor, polymyxin $\mathrm{B}$, for $30 \mathrm{~min}$. BEAS-2B cells were incubated in duplicate with these treated stimuli for $8 \mathrm{~h}$ at $37^{\circ} \mathrm{C}$ and the amounts of IL- 8 in the supernatants were measured by ELISA. Heat treatment abolished the Alternaria's activity to induce IL-8 production. Polymyxin B did not inhibit Alternaria-induced IL-8 production. $\mathrm{M} \pm \mathrm{SE}, \mathrm{n}=5$. Student's $\mathrm{t}$ test was used. ${ }^{*} \mathrm{p}<0.05$, compared to medium alone.

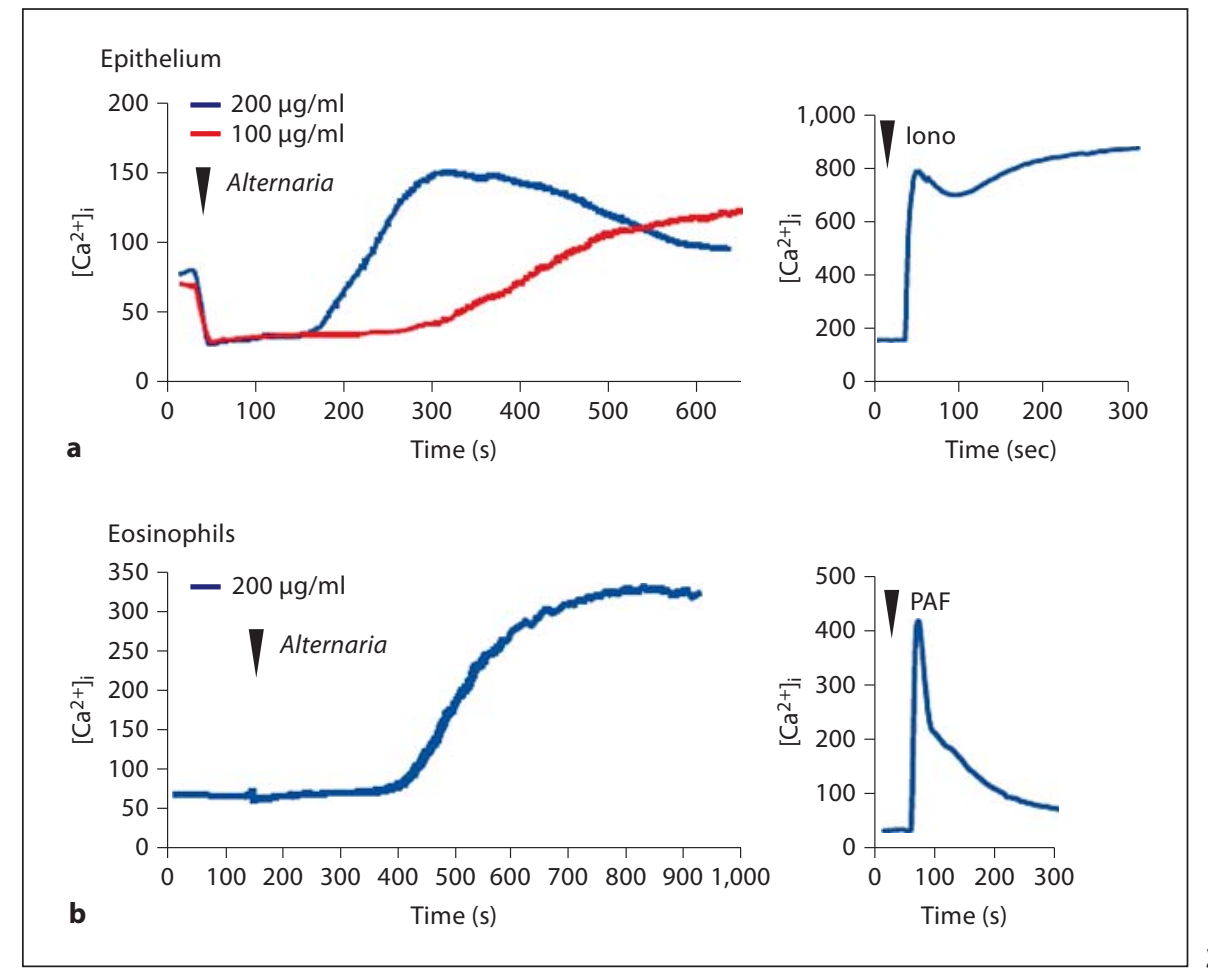

3

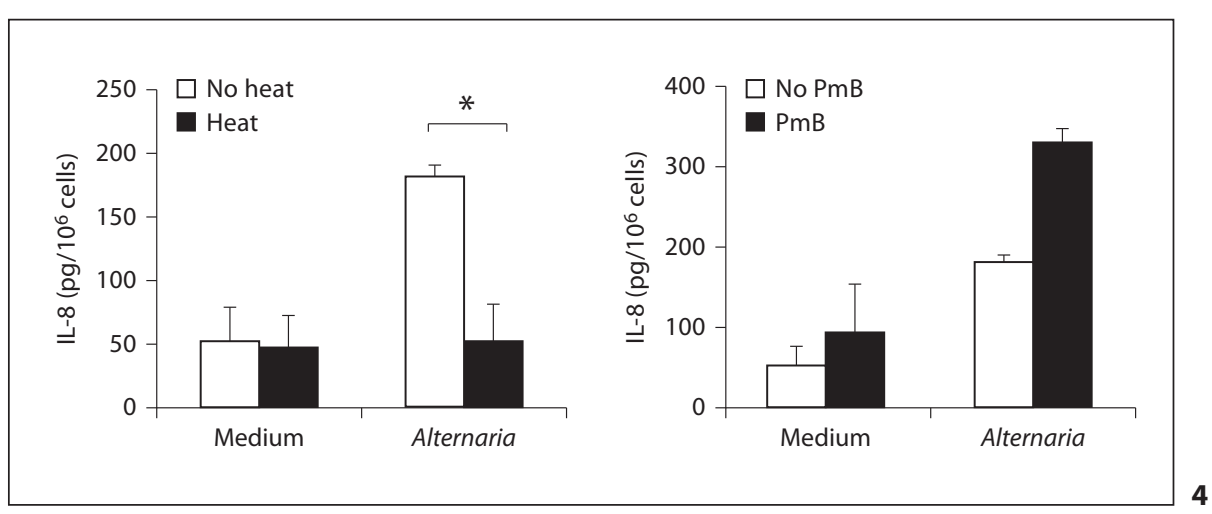

\section{Aspartate Protease Activity in Alternaria Extract}

\section{Activates Airway Epithelial Cells}

Fungi produce large quantities of proteases [1], and heat treatment of Alternaria extract at $56^{\circ} \mathrm{C}$ for $30 \mathrm{~min}$ destroys its ability to induce eosinophil activation and degranulation [20]. Therefore, we examined whether protease-like activity is involved in cytokine production by epithelial cells. First, before incubation with epithelium, aliquots of $100 \mu \mathrm{g} / \mathrm{ml}$ Alternaria extract were heattreated at $56^{\circ} \mathrm{C}$ for $30 \mathrm{~min}$, or were treated at $4^{\circ} \mathrm{C}$ for 30 min. BEAS-2B were then incubated with these treated stimuli for $8 \mathrm{~h}$ at $37^{\circ} \mathrm{C}$. Alternaria extracts, which had been heat-treated $\left(56^{\circ} \mathrm{C}\right)$, did not induce cytokine production, suggesting that heat-labile protein(s) or glycoprotein(s) are involved (fig. 4, left). We also tested whether lipopolysaccharide (LPS), which is present in small amounts in the Alternaria extracts, is involved in Alternaria-induced cytokine production. Before incubation with epithelial cells, aliquots of $100 \mu \mathrm{g} / \mathrm{ml}$ Alternaria extract were preincubated with polymyxin $B$, which binds to the lipid A portion of bacterial LPS. Polymyxin B did not affect Alternaria-induced cytokine production, suggesting that LPS is not involved in these responses (fig. 4, right). 


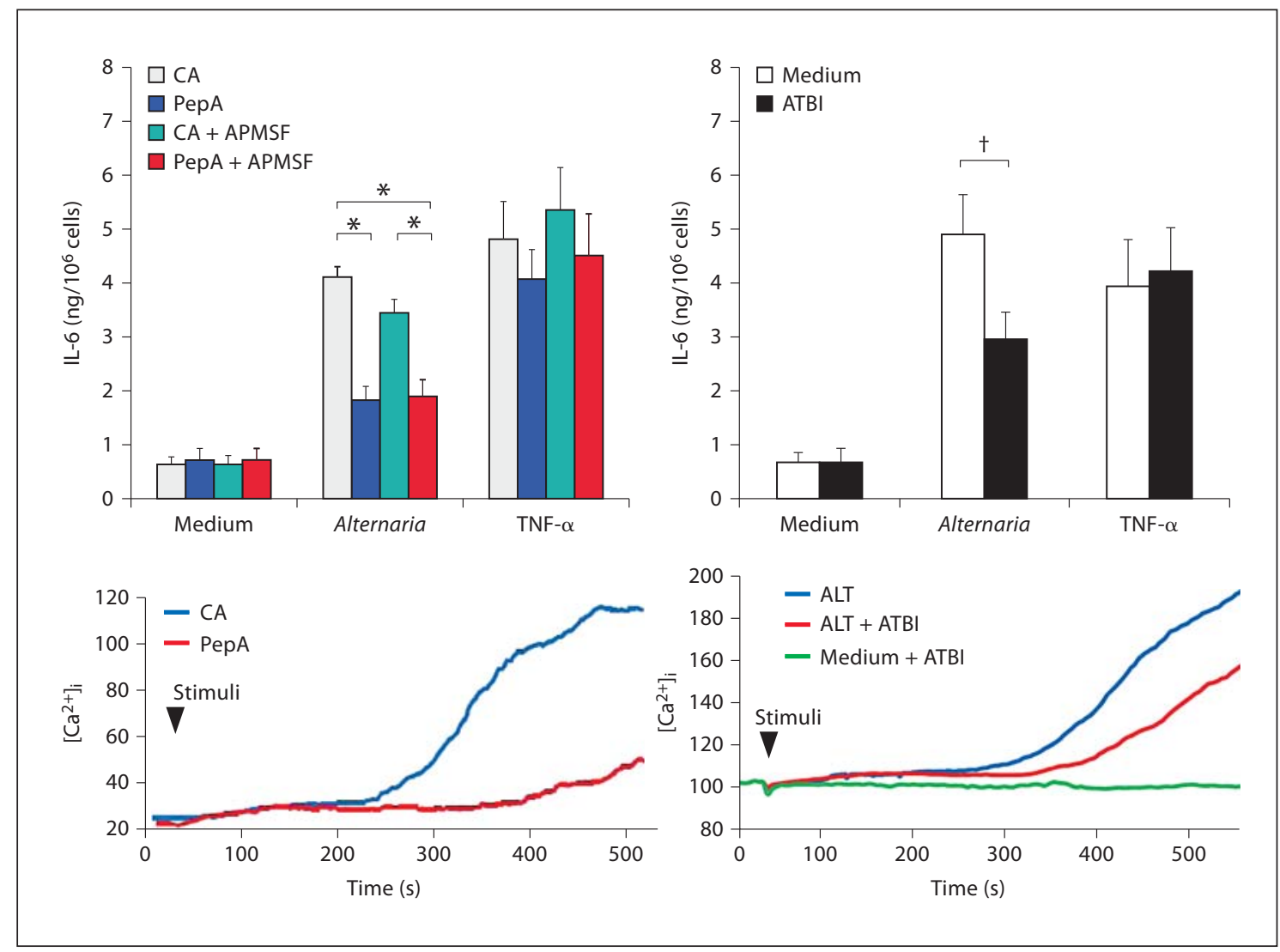

Fig. 5. Effects of protease inhibitors on cytokine production and calcium response to Alternaria extract. Alternaria extracts were pretreated with pepstatin A agarose (PepA) or control agarose (CA). Alternatively, they were pretreated with protease inhibitors including APMSF and ATBI. Treated extracts were added to the monolayer of BEAS-2B cells and cytokine production and $\left[\mathrm{Ca}^{2+}\right]_{\mathrm{i}}$ response were examined. $\mathrm{M} \pm \mathrm{SE}, \mathrm{n}=5 .{ }^{*} \mathrm{p}<0.05,1$-way ANOVA with Tukey's test. ${ }^{\dagger} \mathrm{p}<0.05$, Student's t test.

We next addressed which proteases in Alternaria extracts are involved. We investigated the effects of several protease inhibitors on Alternaria-induced cytokine production and $\left[\mathrm{Ca}^{2+}\right]_{\mathrm{i}}$ response. Both Alternaria extractinduced epithelial cytokine production and $\left[\mathrm{Ca}^{2+}\right]_{i}$ response were significantly inhibited by pepstatin A agarose, but not by control agarose (fig. 5). In contrast, a serine protease inhibitor, APMSF, showed no effects (fig. 5, top). Pepstatin A agarose treatment showed no effects on TNF- $\alpha$-induced cytokine production. ATBI, a bifunctional inhibitor of xylanase and aspartic protease, is reported to inhibit the growth of a variety of fungi. Ritonavir and nelfinavir are well-known aspartate protease inhibitors and are used to treat patients with HIV infection. Both Alternaria-induced cytokine production and $\left[\mathrm{Ca}^{2+}\right]_{i}$ response were inhibited significantly by ATBI (fig. 5), and partially by ritonavir and nelfinavir (data not shown). These findings suggest that aspartate protease(s), but not serine protease(s), in Alternaria extract likely activate airway epithelial cells.

\section{Potential Role of PAR-2 in the Epithelial $\left[\mathrm{Ca}^{2+}\right]_{i}$} Response and Cytokine Production in Response to Alternaria

PARs, in particular PAR2, are used to recognize protease activities and to activate downstream cellular signaling pathways and functions in various cell types. To investigate whether PAR-2 is involved in the epithelial $\left[\mathrm{Ca}^{2+}\right]_{\mathrm{i}}$ response to Alternaria extract, we studied the effects of PAR-2 agonists and antagonists on Alternariainduced $\left[\mathrm{Ca}^{2+}\right]_{\mathrm{i}}$ and cytokine production.

In the study to examine $\left[\mathrm{Ca}^{2+}\right]_{\mathrm{i}}$, cells were incubated with PAR-2 agonist (SLIGKV), PAR-2 antagonist (LSIGKV) or control (GLIVKS) peptides and then stimu- 
Fig. 6. Effects of PAR-2 peptides on IL-6 production and $\left[\mathrm{Ca}^{2+}\right]_{\mathrm{i}}$ response induced by Alternaria extract. BEAS-2B cells or Calu-3 cells were treated with SLIGKV peptide (PAR-2 agonist peptide, blue line), LSIGKV peptide (PAR-2 antagonist peptide, red line), GLIVKS (control peptide, green line) or medium alone (gray line) at $20 \mathrm{~s}$ (first arrow), and then stimulated with Alternaria extract (second arrow). Alternatively, BEAS-2B cells were treated with these peptides or medium alone for $15 \mathrm{~min}$ and then stimulated with Alternaria extract or TNF- $\alpha$ for $24 \mathrm{~h}$ at $37^{\circ} \mathrm{C}$. IL- 6 concentrations in the cell-free supernatants were measured by ELISA. LSIGKV peptide inhibited Alternaria-induced cytokine production. SLIGKV and LSIGKV peptides partially inhibited Alternariainduced increased $\left[\mathrm{Ca}^{2+}\right]_{\mathrm{i}}$. Results show the ratio of control (\%) and mean \pm SEM from 5 different procedures. $\mathrm{n}=5$. Oneway ANOVA with Tukey's test was used. ${ }^{*} \mathrm{p}<0.05$.

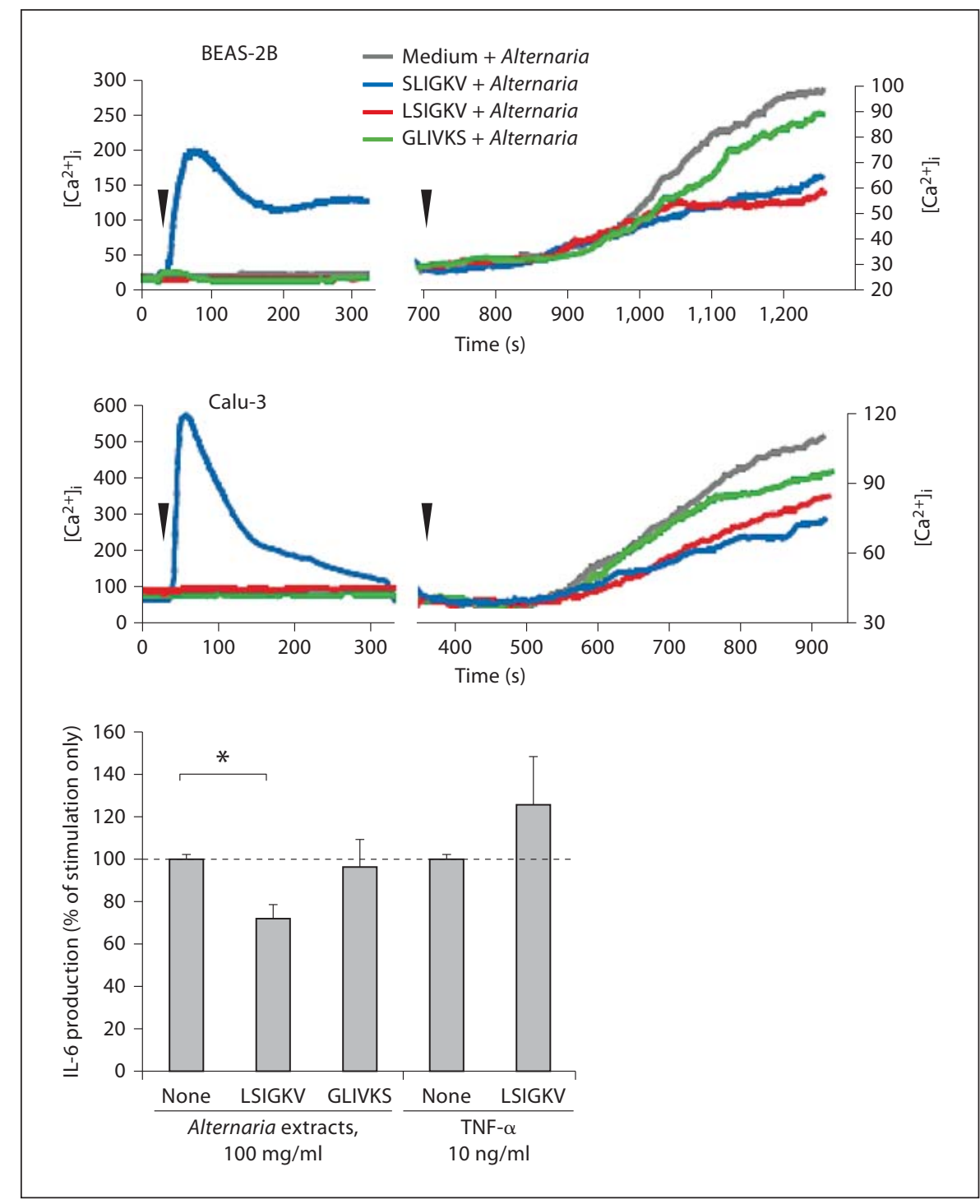

lation with Alternaria extract. SLIGKV induced a quick and marked increased $\left[\mathrm{Ca}^{2+}\right]_{\mathrm{i}}$ response in both BEAS-2B and Calu-3 cells (fig. 6 , top). In contrast, LSIGKV and GLIVKS peptides showed no initial response. Furthermore, SLIGKV and LSIGKV peptides inhibited Alternar$i a$-induced increase in $\left[\mathrm{Ca}^{2+}\right]_{\mathrm{i}}$, suggesting that PAR-2 is involved in the epithelial response to Alternaria extract. To confirm these findings, we preincubated the cells with $100 \mu \mathrm{M}$ LSIGKV, $100 \mu \mathrm{M}$ GLIVKS or medium alone for $15 \mathrm{~min}$ at room temperature before stimulation with 100 $\mu \mathrm{g} / \mathrm{ml}$ Alternaria extract or $10 \mathrm{ng} / \mathrm{ml}$ TNF- $\alpha$ (final concentration) for cytokine production. The LSIGKV peptide partially, but significantly, inhibited Alternaria-induced IL-6 production (fig. 6 , bottom). In contrast, the
GLIVKS showed no effects. Furthermore, the LSIGKV peptide showed no effects on TNF- $\alpha$-induced IL- 6 production, suggesting specificity of the effects of this peptide on the Alternaria response.

\section{Discussion}

In this study, we found that the PAR-2-mediated recognition of aspartate protease activity that is secreted by the actively growing fungus, Alternaria, triggers human epithelial cells to become activated and produce cytokines. These conclusions are based on the following observations. (1) Among several common environmental fungi, 
only A. alternata induced GM-CSF, IL- 6 and IL-8 production, and increased $\left[\mathrm{Ca}^{2+}\right]_{\mathrm{i}}$ response in human epithelial cells, (2) a PAR-2 ligand peptide showed similar cytokine and $\left[\mathrm{Ca}^{2+}\right]_{\mathrm{i}}$ response in human epithelial cells, (3) a PAR-2 ligand peptide desensitized the Alternaria-induced $\left[\mathrm{Ca}^{2+}\right]_{\mathrm{i}}$ response, and a modified PAR-2 peptide (i.e. PAR-2 antagonist) inhibited both cytokine production and $\left[\mathrm{Ca}^{2+}\right]_{\mathrm{i}}$ response, (4) heat treatment of Alternaria extract destroyed its ability to induce epithelium cytokine production, suggesting protease-like activity, and (5) various aspartate protease inhibitors, but not serine protease inhibitors, reduced the Alternaria-induced $\left[\mathrm{Ca}^{2+}\right]_{\mathrm{i}}$ response and cytokine production in human epithelial cells.

Similar to the previous human eosinophil study, among 7 common environmental fungi, only A. alternata was able to activate human airway epithelial cells [20]. Human eosinophils are activated by live A. alternata organisms, release their granule proteins, and kill the fungi [22]. Eosinophils, but not neutrophils, responded to secreted products from A. alternata [20]. We also found that eosinophils are equipped with innate cellular activation machinery that responds to the extracellular aspartate protease activity secreted by Alternaria [15]. Therefore, the eosinophil response to Alternaria likely involves a novel mechanism to activate PAR-2 compared to its activation by serine protease. Generally, PAR-2 is cleaved by trypsin or trypsin-like proteases at a specific site, between Arg36 and Ser37 (Arg36/Ser37). The aspartate protease(s) in Alternaria extract cleaves human PAR2 at unique peptide sequence sites (Ser37/Leu38, Leu38/ Ile39) [15], leading to the activation of PAR-2 and eosinophils. A similar mechanism to activate PAR-2 is likely involved in the activation of airway epithelial cells by $\mathrm{Al}$ ternaria extract because PAR-2 structure in eosinophils and epithelial cells is similar.

Fungi produce various proteases for them to germinate and grow and to invade the hosts. Interestingly, not only Alternaria extracts but also the extracts of Aspergillus, Cladosporium, Penicillium and Bipolaris cleaved PAR-2 substrate (SKGRSLIGKV) in a dose-dependent manner (data not shown). Furthermore, aspartate protease activities were also contained in the extracts of Aspergillus, Penicillium and Bipolaris (data not shown). Therefore, we speculate the differences in the immunostimulatory activities of these fungal extracts may be explained by the peptide specificity of these enzymes. If the N-terminus of PAR-2 is cleaved distal to the Leu38/Ile39 site, the receptor is not activated [15]. Thus, appropriate specificity and amount of protease are likely necessary to activate PAR-2 optimally.

Innate Immune Response of Airway

Epithelium to Fungus
Airway epithelium is considered an active participant in allergic inflammation $[23,24]$. The activation of PAR2 on epithelial cells produces a plethora of proinflammatory mediators, such as eotaxin [25], GM-CSF [25], IL-6 $[16,26]$, IL-8 [16, 26], IL-33 [14], TSLP [11], PGE2 [27] and matrix metalloproteinases [28]. These mediators may induce the accumulation of inflammatory cells and prolong their survival at the sites of inflammation. The differential expression of cytokines (e.g. GM-CSF) and chemokines (e.g. eotaxin) is potentially interesting. While the mechanisms to explain this observation need further study, we bring two reasons as speculation. First, the intracellular signaling mechanisms induced by Alternaria may activate the cytokine genes but not the chemokine genes. Alternatively, epithelial cells may need to be primed optimally in order to produce chemokines in response to Alternaria. For example, the expression of eotaxin by airway epithelial cells is induced by TNF- $\alpha$ and it is enhanced synergistically by pretreating the cells with IL-13 [29].

GM-CSF is known as a pleiotropic and proinflammatory cytokine and is a major survival and activating factor for hematopoietic cells including mature macrophages, eosinophils and neutrophils [30]. The respiratory epithelium produces significant amounts of GM-CSF, and infiltrating leukocytes can be induced to synthesize GM-CSF as an autocrine growth factor by inflammatory and chemotactic stimuli. GM-CSF can also greatly enhance leukocyte oxidative burst activity and mediator release $[31,32]$. Indeed, adenoviral-mediated GM-CSF gene transfer in the lung induced lung eosinophilia, airway fibrosis and marked macrophage accumulation [33]. GMCSF also primes sensitization to allergens in the airways and is directly implicated in the inflammatory responses of respiratory pollutants [34]. It is produced by both Th1 and Th2 cells and is responsible for promoting the differentiation of eosinophils from promyelocytes. Its expression in epithelial cells is increased in patients with allergic rhinitis, nasal polyps and asthma $[35,36]$. Because it is produced by macrophages, eosinophils and epithelial cells of asthmatic patients [37], its endogenous production likely has an important role in the pathogenesis of allergic diseases and asthma. IL-6 is another key cytokine involved in chronic inflammation of the airways. An increased level of soluble IL- 6 receptor is observed in the airways of patients with allergic asthma compared to those in control individuals [38]. IL-6 induces the expansion of Th cells and suppresses the activity of T regulatory cells $[38,39]$. In many chronic inflammatory diseases, including asthma, IL-6 trans-signaling

Int Arch Allergy Immunol 2012;158(suppl 1):19-29 
is critically involved in the maintenance of a disease state, by promoting a transition from acute to chronic inflammation [40]. IL-8 is an important activator and chemoattractant for polymorphonuclear leukocytes and has been implicated in a variety of inflammatory diseases, such as asthma [41]. IL-8 protein is secreted at low levels from cells that have not been stimulated, but its production is rapidly induced by a wide range of stimuli encompassing proinflammatory cytokines [42], bacterial or viral products $[43,44]$ and cellular stressors $[45,46]$.

In summary, our findings suggest that human epithelial cells produce biologically important cytokines, including GM-CSF, IL-6, and IL-8 in response to a fungus, Alternaria. Furthermore, a protease-sensing receptor, PAR-2, is likely involved in epithelial recognition of the fungus. Thus, activation of airway epithelium by the airborne fungus, Alternaria, may be implicated in the de- velopment and exacerbation of airway allergic disease, such as asthma. Antifungal, antiprotease and/or antiPAR-2 therapy may need to be considered as candidates for new treatments for asthma and other airway allergic diseases.

\section{Acknowledgements}

This work was supported in part by Grant AI34486 and AI49235 from the National Institutes of Health, and by the Mayo Foundation.

\section{Disclosure Statement}

The authors declare that no financial or other conflict of interest exists in relation to the contents of this article.

\section{References}

$\checkmark 1$ Denning DW, O’Driscoll BR, Hogaboam CM, Bowyer P, Niven RM: The link between fungi and severe asthma: a summary of the evidence. Eur Respir J 2006;27:615-626.

-2 Bush RK, Prochnau JJ: Alternaria-induced asthma. J Allergy Clin Immunol 2004;113: 227-234.

-3 Zureik M, Neukirch C, Leynaert B, Liard R, Bousquet J, Neukirch F: Sensitisation to airborne moulds and severity of asthma: cross sectional study from European Community Respiratory Health Survey. BMJ 2002;325: 411-414.

-4 O'Hollaren MT, Yunginger JW, Offord KP, Somers MJ, O'Connell EJ, Ballard DJ, Sachs MI: Exposure to an aeroallergen as a possible precipitating factor in respiratory arrest in young patients with asthma. N Engl J Med 1991;324:359-363.

5 Salvaggio J, Seabury J, Schoenhardt FA: New Orleans Asthma. V. Relationship between Charity Hospital asthma admission rates, semiquantitative pollen and fungal spore counts, and total particulate aerometric sampling data. J Allergy Clin Immunol 1971; 48:96-114.

6 Diamond G, Legarda D, Ryan LK: The innate immune response of the respiratory epithelium. Immunol Rev 2000;173:27-38.

7 Mayer AK, Dalpke AH: Regulation of local immunity by airway epithelial cells. Arch Immunol Ther Exp (Warsz) 2007;55:353-362.

-8 Moranta D, Regueiro V, March C, Llobet E, Margareto J, Larrarte E, Garmendia J, Bengoechea JA: Klebsiella pneumoniae capsule polysaccharide impedes the expression of beta-defensins by airway epithelial cells. Infect Immun 2010;78:1135-1146. $\checkmark 9$ Reed CE, Kita H: The role of protease activation of inflammation in allergic respiratory diseases. J Allergy Clin Immunol 2004;114: 997-1008; quiz 1009

10 Knight DA, Lim S, Scaffidi AK, Roche N, Chung KF, Stewart GA, Thompson PJ: Protease-activated receptors in human airways: upregulation of PAR-2 in respiratory epithelium from patients with asthma. J Allergy Clin Immunol 2001;108:797-803.

-11 Kouzaki H, O’Grady SM, Lawrence CB, Kita $\mathrm{H}$ : Proteases induce production of thymic stromal lymphopoietin by airway epithelial cells through protease-activated receptor-2. J Immunol 2009;183:1427-1434.

12 Wang $\mathrm{YH}$, Ito T, Homey B, Watanabe N, Martin R, Barnes CJ, McIntyre BW, Gilliet M, Kumar R, Yao Z, Liu YJ: Maintenance and polarization of human Th2 central memory T cells by thymic stromal lymphopoietin-activated dendritic cells. Immunity 2006;24: 827-838.

13 Ying S, O’Connor B, Ratoff J, Meng Q, Mallett K, Cousins D, Robinson D, Zhang G, Zhao J, Lee TH, Corrigan C: Thymic stromal lymphopoietin expression is increased in asthmatic airways and correlates with expression of Th2-attracting chemokines and disease severity. J Immunol 2005;174:81838190.

14 Kouzaki H, Iijima K, Kobayashi T, O’Grady $\mathrm{SM}$, Kita $\mathrm{H}$ : The danger signal, extracellular ATP, is a sensor for an airborne allergen and triggers IL-33 release and innate Th2type responses. J Immunol 2011;186:43754387.
15 Matsuwaki Y, Wada K, White TA, Benson LM, Charlesworth MC, Checkel JL, Inoue Y, Hotta K, Ponikau JU, Lawrence CB, Kita H: Recognition of fungal protease activities induces cellular activation and eosinophil-derived neurotoxin release in human eosinophils. J Immunol 2009;183:6708-6716.

16 Kauffman HF, Tomee JF, van de Riet MA, Timmerman AJ, Borger P: Protease-dependent activation of epithelial cells by fungal allergens leads to morphologic changes and cytokine production. J Allergy Clin Immunol 2000;105:1185-1193.

$\checkmark 17$ Hansel TT, De Vries IJ, Iff T, Rihs S, Wandzilak M, Betz S, Blaser K, Walker C: An improved immunomagnetic procedure for the isolation of highly purified human blood eosinophils. J Immunol Methods 1991;145: 105-110.

18 Markwardt KL, Magnino PE, Pang IH: Effect of histamine on phosphoinositide turnover and intracellular calcium in human ciliary muscle cells. Exp Eye Res 1996;62:511-520.

19 Grynkiewicz G, Poenie M, Tsien RY: A new generation of $\mathrm{Ca}_{2}^{+}$indicators with greatly improved fluorescence properties. J Biol Chem 1985;260:3440-3450.

20 Inoue Y, Matsuwaki Y, Shin SH, Ponikau JU, Kita H: Nonpathogenic, environmental fungi induce activation and degranulation of human eosinophils. J Immunol 2005; 175 : 5439-5447.

21 Kernen P, Wymann MP, von Tscharner V, Deranleau DA, Tai PC, Spry CJ, Dahinden CA, Baggiolini M: Shape changes, exocytosis, and cytosolic free calcium changes in stimulated human eosinophils. J Clin Invest 1991;87:2012-2017. 
-22 Yoon J, Ponikau JU, Lawrence CB, Kita H: Innate antifungal immunity of human eosinophils mediated by a beta 2 integrin, CD11B. J Immunol 2008;181:2907-2915.

$\checkmark 23$ Kato A, Schleimer RP: Beyond inflammation: Airway epithelial cells are at the interface of innate and adaptive immunity. Curr Opin Immunol 2007;19:711-720.

24 Saenz SA, Taylor BC, Artis D: Welcome to the neighborhood: epithelial cell-derived cytokines license innate and adaptive immune responses at mucosal sites. Immunol Rev 2008;226:172-190.

25 Vliagoftis H, Befus AD, Hollenberg MD, Moqbel R: Airway epithelial cells release eosinophil survival-promoting factors (GMCSF) after stimulation of proteinase-activated receptor 2. J Allergy Clin Immunol 2001; 107:679-685.

-26 Asokananthan N, Graham PT, Fink J, Knight DA, Bakker AJ, McWilliam AS, Thompson PJ, Stewart GA: Activation of protease-activated receptor (PAR)-1, PAR-2, and PAR-4 stimulates IL-6, IL-8, and prostaglandin E2 release from human respiratory epithelial cells. J Immunol 2002;168:3577-3585.

-27 Cocks TM, Fong B, Chow JM, Anderson GP, Frauman AG, Goldie RG, Henry PJ, Carr MJ, Hamilton JR, Moffatt JD: A protective role for protease-activated receptors in the airways. Nature 1999;398:156-160.

28 Vliagoftis H, Schwingshackl A, Milne CD, Duszyk M, Hollenberg MD, Wallace JL, Befus AD, Moqbel R: Proteinase-activated receptor-2-mediated matrix metalloproteinase-9 release from airway epithelial cells. J Allergy Clin Immunol 2000;106:537-545.

29 Matsukura S, Stellato C, Georas SN, Casolaro V, Plitt JR, Miura K, Kurosawa S, Schindler U, Schleimer RP: Interleukin-13 upregulates eotaxin expression in airway epithelial cells by a STAT6-dependent mechanism. Am J Respir Cell Mol Biol 2001;24: 755-761.

30 Tai PC, Spry CJ: The effects of recombinant granulocyte-macrophage colony-stimulating factor (GM-CSF) and interleukin-3 on the secretory capacity of human blood eosinophils. Clin Exp Immunol 1990;80:426434.
31 Hamilton JA: GM-CSF in inflammation and autoimmunity. Trends Immunol 2002;23: 403-408.

32 Fleetwood AJ, Cook AD, Hamilton JA: Functions of granulocyte-macrophage colonystimulating factor. Crit Rev Immunol 2005; 25:405-428.

-33 Xing Z, Ohkawara Y, Jordana M, Graham F, Gauldie J: Transfer of granulocyte-macrophage colony-stimulating factor gene to rat lung induces eosinophilia, monocytosis, and fibrotic reactions. J Clin Invest 1996;97: 1102-1110.

4 Stampfli MR, Wiley RE, Neigh GS, Gajewska BU, Lei XF, Snider DP, Xing Z, Jordana M: GM-CSF transgene expression in the airway allows aerosolized ovalbumin to induce al lergic sensitization in mice. J Clin Invest 1998;102:1704-1714.

35 Ohtoshi T, Vancheri C, Cox G, Gauldie J, Dolovich J, Denburg JA, Jordana M: Monocytemacrophage differentiation induced by human upper airway epithelial cells. Am J Respir Cell Mol Biol 1991;4:255-263.

36 Saha S, Doe C, Mistry V, Siddiqui S, Parker $\mathrm{D}$, Sleeman M, Cohen ES, Brightling CE: Granulocyte-macrophage colony-stimulating factor expression in induced sputum and bronchial mucosa in asthma and COPD. Thorax 2009;64:671-676.

- 37 Robinson DS, Hamid Q, Ying S, Tsicopoulos A, Barkans J, Bentley AM, Corrigan C, Durham SR, Kay AB: Predominant Th2-like bronchoalveolar T-lymphocyte population in atopic asthma. N Engl J Med 1992;326: 298-304.

38 Doganci A, Sauer K, Karwot R, Finotto S: Pathological role of IL- 6 in the experimental allergic bronchial asthma in mice. Clin Rev Allergy Immunol 2005;28:257-270.
39 Doganci A, Eigenbrod T, Krug N, De Sanctis GT, Hausding M, Erpenbeck VJ, Haddad el B, Lehr HA, Schmitt E, Bopp T, Kallen KJ, Herz U, Schmitt S, Luft C, Hecht O, Hohlfeld JM, Ito H, Nishimoto N, Yoshizaki K, Kishimoto T, Rose-John S, Renz H, Neurath MF, Galle PR, Finotto S: The IL-6R alpha chain controls lung CD4+CD25+ Treg development and function during allergic airway inflammation in vivo. J Clin Invest 2005;115: 313-325.

- 40 Rose-John S, Scheller J, Elson G, Jones SA Interleukin- 6 biology is coordinated by membrane-bound and soluble receptors: role in inflammation and cancer. J Leukoc Biol 2006;80:227-236.

-41 Strieter RM: Interleukin-8: a very important chemokine of the human airway epithelium. Am J Physiol Lung Cell Mol Physiol 2002; 283:L688-689.

-42 Kasahara T, Mukaida N, Yamashita K, Yagisawa $H$, Akahoshi T, Matsushima K: IL-1 and TNF-alpha induction of IL-8 and monocyte chemotactic and activating factor (MCAF) mRNA expression in a human astrocytoma cell line. Immunology 1991;74: 60-67.

43 Hobbie S, Chen LM, Davis RJ, Galan JE: Involvement of mitogen-activated protein kinase pathways in the nuclear responses and cytokine production induced by Salmonella typhimurium in cultured intestinal epithelial cells. J Immunol 1997;159:55505559.

44 Johnston SL, Papi A, Bates PJ, Mastronarde JG, Monick MM, Hunninghake GW: Low grade rhinovirus infection induces a prolonged release of IL-8 in pulmonary epithelium. J Immunol 1998;160:6172-6181.

-45 Hirota R, Akimaru K, Nakamura H: In vitro toxicity evaluation of diesel exhaust particles on human eosinophilic cell. Toxicol In Vitro 2008;22:988-994.

-46 Fritz EA, Jacobs JJ, Glant TT, Roebuck KA: Chemokine IL- 8 induction by particulate wear debris in osteoblasts is mediated by NFkappaB. J Orthop Res 2005;23:1249-1257.
Innate Immune Response of Airway Epithelium to Fungus
Int Arch Allergy Immunol

2012;158(suppl 1):19-29 